\title{
Performance and job creation among self-employed immigrants and natives in Sweden
}

\author{
Emma Neuman (iD)
}

Accepted: 18 June 2019/Published online: 26 June 2019

(C) The Author(s) 2019

\begin{abstract}
This paper uses individual-level panel data for all self-employed in the retail and service sectors to study how immigrant- and native-owned firms perform and contribute to job creation in Sweden. We use an individual fixed-effects model to explore how selfemployment outcomes among immigrants and natives evolve with self-employment experience. The advantage of our approach is that it enables estimations of the returns to self-employment experience while controlling for unobservable time-constant individual factors. The results show that profits increase with selfemployment experience and at a faster rate among immigrant men and women than for their native counterparts. Turnover and the likelihood of having employees both increase with experience and in a similar magnitude for immigrants and natives.
\end{abstract}

Keywords Immigrant businesses - Job creation · Performance · Self-employment $\cdot$ Self-employment experience

JEL classification $\mathrm{J} 15 \cdot \mathrm{J} 61 \cdot \mathrm{L} 25 \cdot \mathrm{L} 26$

The author thanks the editor Rui Baptista, two anonymous referees, Lina Aldén and Mats Hammarstedt and participants at the 29th EALE conference 2017 in St Gallen for useful comments and suggestions.

E. Neuman $(\bowtie)$

Centre for Discrimination and Integration Studies, Linnaeus

University, 35195 Växjö, Sweden

e-mail: emma.neuman@lnu.se

\section{Introduction}

Immigration has increased rapidly in many countries. The integration of immigrants into the labour market of their host countries has received attention from researchers and politicians. In Sweden, the share of the population born abroad nearly doubled between 1970 and 2000 (Statistics Sweden n.d.). ${ }^{1}$ Over time, the migration flows have shifted from consisting mainly of labour-force migrants from Europe, to refugees and tied-movers from outside of Europe. In Sweden, as in other countries, immigrants underperform natives on the labour market. Self-employment has often been suggested as a way to increase labour market attachment among the foreign born. In several countries, immigration policies have been constructed to facilitate immigration of potential entrepreneurs (Schuetze and Antecol 2006; Fairlie and Lofstrom 2015). In Sweden, the government proposes increased self-employment rates among the newly arrived immigrants as a way to make better use of their competencies (SOU 2015/16:100).

Previous research has shown that immigrants in many developed countries are more likely than natives to be self-employed (see e.g. Borjas 1986; Fairlie and Meyer 1996; Fairlie and Robb 2007; Robb and Fairlie 2009 for studies on the US, and e.g. Clark and Drinkwater 2000, 2010; Hammarstedt 2001; Constant and Zimmermann 2006; Andersson and Hammarstedt 2011 for studies on European countries). However, it

\footnotetext{
${ }^{1}$ A detailed description of the history of migration to Sweden is provided by Lundh and Ohlsson (1999).
} 
appears that self-employed immigrants face more difficulties in attaining capital and understanding laws and regulations than do self-employed natives (e.g. Blanchflower et al. 2003; Blanchard et al. 2008; Asiedu et al. 2012; Aldén and Hammarstedt 2016) and that limited proficiency in the host country language restricts immigrant self-employment (Bates 1999). These difficulties might reduce as immigrants become more experienced in self-employment; we have reason to expect immigrant firms to be less successful and to grow more slowly than native firms in the start-up phase. However, it is still unknown whether the potential differences in performance and job creation between immigrants and natives remain as the owners gain experience with self-employment.

Until now, few studies have investigated how immigrants' and natives' self-employment outcomes develop with business experience. Lofstrom (2011) studies how the earnings among low-skilled self-employed immigrants and natives in the US evolve with years in business. He finds that the earnings of self-employed immigrant men increase with years in business and at a faster rate than for native men. Among women, self-employed immigrants initially have a similar earnings growth as self-employed natives, but after about 5 years, immigrants' earnings decrease with additional years in business. In this paper, we contribute to this literature by studying how immigrant- and native-owned firms in Sweden grow, both by adding employees and improving their performance, as they gain self-employment experience. Sweden is a suitable country for analysing this question for several reasons. First, Sweden has a large immigrant population and has experienced a large inflow of refugee migrants. Given that immigrants in Sweden encounter large difficulties in the labour market and self-employment plays an important role especially for refugee migrants - who are over-represented in selfemployment ${ }^{2}$ - it is important to analyse immigrants' self-employment performance in Sweden. Second, research show that immigrants in Sweden face difficulties in attaining capital when they opt for self-employment and struggle to survive in business when they are established (Andersson Joona 2010; Aldén and Hammarstedt 2016). However, other countries have had similar experiences of immigration and difficulties

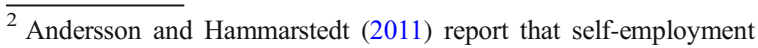
rates are considerably higher among immigrants from countries where many migrants are refugees.
}

for immigrant businesses (see e.g. Parker 2009 for an overview). Thus, self-employment experience might play a similar role for immigrants in other countries and time-periods.

We expand previous literature by being the first study to investigate how immigrant- and native-owned firms' job creation evolves with self-employment experience. The literature on firms' jobs creation and especially on the contribution of immigrant firms to job creation is still scarce (e.g. Kerr and Kerr 2017; Fairlie and Lofstrom 2015). In addition, our paper considers selfemployment income and can complement the results described in Lofstrom (2011) for the USA. In contrast to Lofstrom (2011), we include the full immigrant population and do not focus exclusively on the low-skilled. We analyse both profit and turnover (income from sales). This is important since previous research for Sweden has shown that immigrant businesses generate more sales but at the same time receive lower profits than native-owned firms (e.g. Andersson and Hammarstedt 2011; Aldén and Hammarstedt 2016). There is, in contrast, a large literature on the impacts of migration on the host economy, but few of these studies consider immigrant self-employment. Firms started and operated by immigrants contribute to the host economy, not least by increasing employment and income from self-employment (Fairlie and Lofstrom 2015). Even though it is outside the scope of this paper to consider immigrant firms' total net contribution to the economy, this study can provide further insight into this important aspect of the impact of immigration. Fairlie and Lofstrom (2015) point out that a complete picture of the contribution of immigrant firms to the economy requires inclusion of their effect on innovation and economic growth. One drawback with this study is that we do not have access to data on other measures of selfemployment performance such as e.g. innovation and productivity.

The paper uses Swedish longitudinal register data for the years 1998 to 2007. This data provides information on individual and firm characteristics for all selfemployed natives and immigrants in Sweden. We restrict the focus to self-employed in the retail and service sectors in Sweden. These sectors are of particular relevance for immigrants since many immigrants have established their businesses there (Andersson and Hammarstedt 2011). To our knowledge, few papers have so far explored how self-employment experience matters for job creation and performance among 
immigrants with the help of longitudinal data. We use an individual fixed-effects model that enables us to control for time-constant factors (e.g. motivation, talent and/or ability), and selection out from self-employment - that could bias the estimate of the effect of self-employment experience on performance and job creation. In addition, our regressions include several time-varying control variables, but it is still possible that omitted timevarying factors bias our estimates.

The remainder of the paper is organized as follows. Section 2 describes the previous literature. Section 3 presents the data and summary statistics. Section 4 provides the empirical model and results. Finally, Sect. 5 concludes.

\section{Literature review}

2.1 The self-employment performance of immigrants and natives

Self-employment performance among immigrants from different countries has been extensively studied. ${ }^{3} \mathrm{Sev}-$ eral studies have investigated differences in performance between self-employed immigrants and natives. In this literature, it emerges that the self-employment experience of immigrants differs both across host countries and for different immigrant groups. In Sweden, non-European immigrants have lower earnings and profit from their firms than do their native counterparts, while the self-employment performance of immigrants originating from Europe is more similar to native performance (Hammarstedt 2006; Andersson and Hammarstedt 2011; Andersson Joona 2011). Evidence for the US shows that immigrant businesses-owners have lower earnings than do self-employed natives (Lofstrom 2002). However, Asian-owned businesses, most of which are immigrant owned, have higher sales and profits than native-owned ones (Robb and Fairlie 2009).

Any study of immigrant earnings must take into account the duration of stay in the host country. A large literature on immigrant earnings assimilation in the wage sector has shown that immigrants initially tend to have lower earnings than natives, but this disparity decreases as time in the host country increases (see e.g.

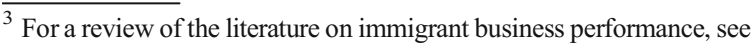
Fairlie and Lofstrom (2015).
}

Chiswick 1978; Borjas 1985). A few papers have expanded the immigrant assimilation literature to the selfemployment sector. Lofstrom $(2002,2011)$ finds that the earnings of self-employed immigrants in the USA converge with or even surpass the earnings of selfemployed natives as they age. In Canada and Australia, it takes longer for self-employed immigrants to reach earnings parity with natives than it does in the USA (Schuetze and Antecol 2006).

The literature on immigrant self-employment offers several theoretical explanations for the fact that immigrants gain less than natives in self-employment. To start with, immigrant business owners might face discrimination from native consumers, forcing them to lower prices to attract them (Borjas and Bronars 1989), and/or from credit institutes, which could increase their financing costs (see e.g. Blanchflower et al. 2003; Aldén and Hammarstedt 2016). In addition, immigrants can be discriminated against by employers in the paid labour market, pushing them into self-employment (Clark and Drinkwater 2000). Discrimination and lack of labour market skills (work experience, language skills, and education) could induce immigrants to enter selfemployment due to a lack of other alternatives (e.g. Simoes et al. 2016). This could result in immigrants being less motivated and/or skilled and thus less successful in self-employment than natives. In addition, the fact that immigrants are pushed into self-employment could reduce their reservation wages to enter self-employment, making them willing to accept lower incomes from their businesses (Andersson Joona 2011).

The literature investigating important factors for job creation among the self-employed is rather scarce (Henley 2005; Fairlie and Miranda 2017). Namely, there are few studies of ethnic differences in job creation. Andersson and Hammarstedt (2011) find that in Sweden, firms owned by non-European immigrants tend to have more employees and higher turnover than do natives' and European immigrants' firms. In contrast, Henley (2005) finds that ethnic minorities in the UK are less likely than natives to hire employees. Recent evidence from the USA also shows that immigrant and native business owners tend to hire employees to the same extent if individual differences are taken into account (Fairlie and Miranda 2017). Although, among firms having survived 3 years in business in the USA, immigrant business owners hire additional personnel at a faster rate than natives (Kerr and Kerr 2017). 
To date, the theoretical literature on job creation by the self-employed is sparse (Parker 2009). Cowling et al.'s (2004) theoretical model suggests that greater entrepreneurial human capital makes it more likely for an individual to become a job-creator instead of selfemployed without employees. However, higher entrepreneurial human capital is unlikely to explain the empirical finding that immigrant firms have more employees than native firms. As described above, the literature on the native-immigrant earnings differential in self-employment suggests that immigrants entering self-employment are negatively selected in terms of skills, education and motivation. Kloosterman (2010) argues that immigrants might be more prone to access markets that have low entry barriers in terms of being small and requiring few skills, and are characterised by labour-intensive production, stagnant demand, and low profits. Similarly Waldinger et al. (1990) find that immigrant business owners are more likely to run marginal and labour-intensive businesses directed at co-ethnic and/or low-income customers. In addition, immigrants, and especially those establishing businesses in ethnic enclaves, might benefit from the possibility to recruit coethnics and also by paying them below-market wages (Parker 2009; Blackburn and Ram 2006). In other words, immigrants might enter sectors and/or market segments where production requires many employees but where prospects for high profits are low. Kloosterman (2010) argues that these type of businesses are found in the retail and restaurant sectors; this is also where many immigrants in Sweden establish their businesses (Andersson and Hammarstedt 2011).

Apart from ethnic differences in self-employment performance, there are large differences in performance between men and women. It is well established in the literature that self-employed women have lower earnings and profit (e.g. Parker 2009) and hire fewer employees than self-employed men (e.g. van Praag and Cramer 2001; Fairlie and Miranda 2017; Burke et al. 2002; Henley 2005). Economic theory offers several explanations for these gender differences. To start with, the fact that women are on average more risk-averse than men could lead them to be more careful when taking decisions on the amount of capital to invest in their businesses (Parker 2009). At the same time, women are less inclined to seek external finance and depend more on their own resources (Carter and Shaw 2006). This could result in women having fewer possibilities to expand their businesses by hiring more employees, and also in earning less from their self-employment activities. Moreover, self-employed men seem to benefit more from social capital in terms of having more diversified and powerful networks and contacts (Koellinger et al. 2013). Finally, women and men might have different preferences and reasons for engaging in self-employment. Men tend to enter self-employment because of higher potential returns, whereas women are driven by better possibilities to balance work and family life and greater flexibility (Wellington 2006; Gurley-Calvez et al. 2009). Thus non-pecuniary benefits might induce women to enter and stay in self-employment despite the low income. In addition, women might enter selfemployment because of discrimination in paid employment (Parker 2009), implying that they might have a lower reservation wage to enter, and are willing to accept lower incomes from their businesses.

\subsection{The role of self-employment experience}

A large amount of human capital is of great importance for successful self-employment. For the self-employed, age, education and experience are the most relevant components of human capital. ${ }^{4}$ Older people have more years of labour market experience, more wisdom and knowledge of institutions, better social and business networks, and more financial capital, making them more likely to enter and succeed at self-employment (Cowling et al. 2004; Constant et al. 2007). Many people often start their own businesses in the same type of industry as the one in which they had previously held paid employment. Shane (2003) asserts that the industry-specific information and skills gathered when working raise the expected value of exploitation and increase individuals' effort at start-up. In addition to the experience attained along with ageing and working, specific experience from self-employment might prove valuable for selfemployment performance. Someone who has been self-employed might have learnt about business opportunities and acquired skills in selling, negotiating, leading, planning, decision-making, problem-solving, organising and communicating (Cowling et al. 2004; Parker 2009; Shane 2003). Against this background, it seems reasonable to expect self-employment performance to improve with age, labour market experience and experience from spells of self-employment. To date,

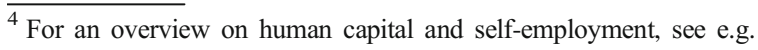
Parker (2009).
} 
few studies have distinguished the impact of experience in paid employment from that of experience in selfemployment on individuals' performance in selfemployment (Van der Sluis et al. 2008). In general, the empirical evidence that previous experience from being self-employed enhances performance as self-employed is mixed (Burke et al. 2002; Shane 2003; Van der Sluis et al. 2008). Storey (1994) argues that more experience from self-employment might show that the selfemployed have learnt the relevant skills for successful self-employment, and that they had previously been self-employed but failed because of a lack of managerial ability. The mixed empirical results on the role of selfemployment experience for self-employment performance might be due to the lack of distinction between experience from current and previous spells of selfemployment.

Previous literature has focused on differences between immigrants and natives in self-employment performance over the life cycle. However, differences in native and immigrant business performance might also emerge because of variation in length of self-employment. For instance, immigrants might face additional difficulties when starting a business. Research has shown that immigrants and minorities face problems, such as attaining capital and understanding laws and regulations, when they start and run a business (e.g. Blanchflower et al. 2003; Blanchard et al. 2008; Asiedu et al. 2012; Aldén and Hammarstedt 2016). It is also possible that limited proficiency in the host country language restricts immigrant self-employment (Bates 1999), especially initially. We would therefore expect immigrant firms to be less successful and to grow more slowly than native firms at first. Few studies have investigated whether the potential differences in performance between immigrants and natives persist as the owners gain self-employment experience. In a crosssectional study on Germany, Constant et al. (2007) find that longer business tenure is positively correlated with immigrant men's earnings, but not to native men's earnings. To our knowledge, Lofstrom's (2011) is the only study that answers this question with the help of individual panel data. Lofstrom finds that the earnings of low-skilled self-employed immigrant men grow faster than for native men with years in business. The results for low-skilled women show that self-employed immigrant women have a slower earnings growth than selfemployed native women. This suggests that it is important to consider not only ethnic differences but also gender differences when investigating how selfemployment experience affects self-employment performance.

Moreover, in an analysis of the returns to self-employment, it is important to take into account the differences in survival rates, not least to avoid non-random selection out of self-employment which could be related to performance. It has been shown that immigrant firms do not survive as long time as native firms (e.g. Fairlie and Meyer 1996; Bates 1999; Fairlie and Robb 2007; Andersson Joona 2010).

\section{Data}

\subsection{Sample construction}

We use register data from the longitudinal data base LISA provided by Statistics Sweden. The data contains yearly information on individual, demographic and firm characteristics for all individuals in Sweden older than 16 years. We restrict our sample to people in the retail, trade or service sector and who were registered as self-employed in at least 1 year during the period of our study, 1998 to 2007 . We use Statistic Sweden's definition of self-employment and define an individual as self-employed if earnings from self-employment are their main source of income. According to this definition, people with income from both wage-employment and selfemployment are defined as self-employed if 1.6 times the income from self-employment is higher than the income from wage-employment. Selfemployment income is up-weighted with the factor 1.6 since income from self-employment is underestimated in relation to the number of hours spent in this activity. ${ }^{5}$ In the regressions we control for having earnings from wage-employment since this can affect performance in self-employment. Only people who entered self-employment in the period of our study are included, so people who were selfemployed during all 9 years are excluded. The reason is that the data does not include information

\footnotetext{
${ }^{5}$ This factor is calculated by Statistic Sweden based on the information provided in their income statistics. We performed a robustness test where all individuals with income from self-employment are included in the sample. This had little effect on the results for the returns to selfemployment experience, but implied some changes in the observed native-immigrant performance gap at entry.
} 
about years of experience from self-employment prior to 1998, and this implies that information on years in self-employment is unknown for individuals who remained self-employed all 9 years. The individuals who are included can still have experience from earlier spells of self-employment. In the estimations, the individual fixed-effect model will control for the effect of such previous experience. This implies that the return to experience will not be biased by previous experience, but the estimated gap at start-up might be biased by omitted previous self-employment experience. ${ }^{6}$

Furthermore, to capture people with high attachment to the labour market (e.g. not people who are students or part-time retired) we include only individuals aged 25 to 64 years. In total, the number of individual-year observations amounts to 431,371, with 155,081 unique entrants. About 24\% are immigrants and a majority (around $61 \%$ ) are men. Individuals are defined as immigrants if they were born in a country other than Sweden and as natives if they were born in Sweden.

\subsection{Descriptive statistics}

Table 1 presents the performance of self-employed immigrants and natives by years in self-employment, separately for men and women. On average, individuals in our sample stay in business around 1.5 years. A firm's performance is measured by yearly earnings from self-employment, yearly firm turnover (income from sales net of taxes and discounts), and yearly firm profit (income minus costs, excluding deductions related to interest rates and taxes). In addition, the owner's hiring decisions are described by the average number of employees at the firm and the share of firms having at least one employee. It appears that immigrants have more employees than natives and their firms have higher turnover, but at the same time their profits and earnings are lower than natives'. Moreover, men tend to hire more employees than women, and men's firms are more successful. All groups improve their performance as the number of years in selfemployment increases, but not many people stay in

\footnotetext{
${ }^{6}$ For the same reason, we have omitted firm age. It can bias our estimates, since we cannot tell whether an individual has started a new firm or taken over an existing firm.
}

self-employment for the full 8 years. This highlights the importance of utilizing individual fixed effects (i.e. making comparisons within the individual), which will make non-random selection out of selfemployment caused by time-invariant factors like self-employment skills and abilities and/or motivation less of a concern.

Table 2 displays some descriptive statistics for our sample 2 years after start-up, which is slightly above the average length of self-employment experience in our sample. Natives are found to have somewhat higher educational attainment and are about 2 years older than immigrants. Almost half of the native men are active in financial and business services; immigrant men are over-represented among hotel and restaurant owners. Among women, nearly $40 \%$ of natives are active in personal and other services; immigrants are more evenly spread across several sectors. Immigrants are more likely to be married and to have more children than natives. The average length of residence in Sweden is about 18 years for immigrant women, and about 1 year less for immigrant men.

\section{Empirical analysis}

\subsection{Self-employment performance}

Our aim is to study the success of self-employed immigrants in relation to self-employed natives and especially how this is affected by self-employment experience. The descriptive statistics reveal that performance differs across groups; native men have the highest earnings and profits and immigrant men have the highest turnover and the most employees. Overall, men's firms are more successful than women's. Thus, it appears that selfemployment performance differs substantially both along ethnic and gender lines. However, some of the group differences could be explained by individual characteristics such as education, age, family composition or sector. To take into account the differences in observable characteristics, we estimate the following OLS regression separately for men and women.

$Y_{i s j t}=X_{i t} \beta+\rho_{1} T_{i t}+\rho_{2} T_{i t}^{2}+\tau_{t}+\gamma_{s}+\theta_{j}+\varepsilon_{i s j t}$

where $Y_{i s j t}$ is the performance of individual $i$ in sector s, region $\mathrm{j}$, and year $t$. As measures of performance we will 
Table 1 Performance by years since start-up

\begin{tabular}{|c|c|c|c|c|}
\hline & Native men & Immigrant men & Native women & Immigrant women \\
\hline \multicolumn{5}{|l|}{ At year of start-up } \\
\hline Number of employees & 0.24 & 0.35 & 0.22 & 0.28 \\
\hline Share with employees & 9.44 & 19.44 & 8.93 & 14.11 \\
\hline Yearly real earnings(1000 SEK) & 111.33 & 77.75 & 76.29 & 60.51 \\
\hline Yearly real net turnover(1000 SEK) & 67.92 & 80.15 & 52.03 & 65.41 \\
\hline Yearly real operating profit/loss(1000 SEK) & 23.09 & 14.93 & 15.77 & 12.63 \\
\hline Observations & 69,032 & 25,509 & 48,193 & 12,347 \\
\hline \multicolumn{5}{|l|}{ After 4 years } \\
\hline Number of employees & 0.36 & 0.60 & 0.24 & 0.32 \\
\hline Share with employees & 15.06 & 29.45 & 12.06 & 16.25 \\
\hline Yearly real earnings(1000 SEK) & 162.92 & 120.53 & 116.83 & 98.62 \\
\hline Yearly real net turnover(1000 SEK) & 88.78 & 105.00 & 53.31 & 68.79 \\
\hline Yearly real operating profit/loss(1000 SEK) & 27.65 & 19.95 & 18.20 & 16.57 \\
\hline Observations & 12,087 & 5,029 & 9,021 & 1,908 \\
\hline \multicolumn{5}{|l|}{ After 8 years } \\
\hline Number of employees & 0.41 & 0.68 & 0.26 & 0.23 \\
\hline Share with employees & 18.32 & 29.26 & 14.80 & 15.93 \\
\hline Yearly real earnings(1000 SEK) & 174.54 & 137.40 & 126.12 & 103.88 \\
\hline Yearly real net turnover(1000 SEK) & 99.10 & 88.57 & 52.89 & 51.23 \\
\hline Yearly real operating profit/loss(1000 SEK) & 28.24 & 22.27 & 18.87 & 16.23 \\
\hline Observations & 1,212 & 475 & 1,034 & 182 \\
\hline
\end{tabular}

One svensk krona $($ SEK) $\approx$ USD 0.15 in 2007. Earnings, profit, and turnover are expressed in real values, i.e. adjusted for changes in the price level, and includes only individuals with positive values

use the logarithm of yearly turnover and profit. This implies that we exclude observations with values equal to or below zero. ${ }^{7}$ The matrix $X_{i t}$ includes individual characteristics (an indicator variable for being foreign born, a quadratic function of age, educational level, labour earnings, ${ }^{8}$ marital status, number of children, and a quadratic function of years since migration for

\footnotetext{
$\overline{7}$ Twenty-five thousand four hundred fifty-nine observations are excluded in regressions for profit, and 8378 observations are excluded from the turnover regressions. As a robustness check, we have estimated regressions without logarithmic values; these are presented in Table 8 in the Appendix. These results are consistent with the baseline results, although the differences between immigrants' and natives' returns to experience tend to be smaller.

${ }^{8}$ About $28 \%$ of the self-employed in the sample have earnings from wage employment.

${ }^{9}$ A region is defined as a county. Sweden has 21 counties. We have investigated whether the results are robust to specifying years in selfemployment and the other time-variant variables (age and years since migration) as indicator variables instead of continuous variables. This had little impact on the results and does not change the main conclusions. The results are not displayed, but are available from the author upon request.
}

immigrants that is set to zero for natives). $T_{i t}$ is the number of years in self-employment specified as a continuous variable and included as a quadratic function. In addition, the regression includes year fixed effects, $\tau_{t}$, sector fixed effects, $\gamma_{\mathrm{s}}$, and region fixed effects, $\theta_{\mathrm{j}}{ }^{9}$ The year fixed effects are important to include in order to control for macroeconomic changes and business cycle effects. All independent variables are allowed to vary for immigrants and natives, implying that they are interacted with an indicator variable for being foreign born. $\varepsilon_{i s j t}$ is the error term. To get a better picture of how performance evolves with self-employment experience, we use the regression estimates to generate predicted performance-experience profiles for immigrant women, native women, immigrant men and native men separately. The predictions are calculated at the sample means of the explanatory variables and varying the years in selfemployment.

Although Eq. (1) includes a large number of individual characteristics, it is still possible that omitted variables, such as motivation, talent, and/or ability, affect self- 
Table 2 Summary statistics

\begin{tabular}{|c|c|c|c|c|}
\hline & Native men & Immigrant men & Native women & Immigrant women \\
\hline \multirow[t]{2}{*}{ Primary education $(\%)$} & 17.28 & 25.37 & 13.49 & 20.84 \\
\hline & $(37.81)$ & $(43.51)$ & $(34.17)$ & $(40.62)$ \\
\hline \multirow[t]{2}{*}{ Secondary education $(\%)$} & 49.75 & 43.89 & 54.90 & 45.25 \\
\hline & $(50.00)$ & $(49.63)$ & $(49.76)$ & $(49.78)$ \\
\hline \multirow[t]{2}{*}{ Post-secondary or tertiary education $(\%)$} & 32.72 & 27.91 & 31.46 & 31.70 \\
\hline & $(46.92)$ & $(44.86)$ & $(46.44)$ & $(46.53)$ \\
\hline \multirow[t]{2}{*}{ Age } & 45.07 & 42.52 & 44.30 & 42.98 \\
\hline & $(11.18)$ & $(9.05)$ & $(10.50)$ & $(9.42)$ \\
\hline \multicolumn{5}{|l|}{ Sector $(\%)$} \\
\hline \multirow[t]{2}{*}{ Trade and repair of motor vehicles } & 7.83 & 4.42 & 0.85 & 0.54 \\
\hline & $(26.87)$ & $(20.56)$ & $(9.16)$ & $(7.35)$ \\
\hline \multirow[t]{2}{*}{ Wholesale and commission trade } & 6.62 & 4.10 & 3.18 & 4.11 \\
\hline & $(24.87)$ & (19.83) & $(17.56)$ & $(19.86)$ \\
\hline \multirow[t]{2}{*}{ Retail trade } & 10.10 & 17.44 & 14.75 & 19.02 \\
\hline & $(30.13)$ & $(37.95)$ & $(35.46)$ & $(39.25)$ \\
\hline \multirow[t]{2}{*}{ Transportation and warehousing } & 11.28 & 17.35 & 1.91 & 2.13 \\
\hline & (31.64) & $(37.87)$ & (13.69) & (14.44) \\
\hline \multirow[t]{2}{*}{ Postal and telecommunication } & 0.44 & 0.16 & 0.08 & 0.06 \\
\hline & $(6.58)$ & $(3.97)$ & $(2.85)$ & $(2.50)$ \\
\hline \multirow[t]{2}{*}{ Financial and business services } & 45.91 & 15.93 & 34.31 & 24.89 \\
\hline & $(49.83)$ & $(36.60)$ & $(47.48)$ & $(43.24)$ \\
\hline \multirow[t]{2}{*}{ Hotels and restaurants } & 3.73 & 32.22 & 5.60 & 20.71 \\
\hline & $(18.95)$ & $(46.73)$ & $(23.00)$ & $(40.53)$ \\
\hline \multirow[t]{2}{*}{ Personal and other services } & 14.09 & 8.37 & 39.31 & 28.52 \\
\hline & $(34.79)$ & $(27.70)$ & $(48.85)$ & $(45.16)$ \\
\hline \multirow[t]{2}{*}{ Married (\%) } & 47.45 & 67.87 & 51.63 & 64.11 \\
\hline & $(49.94)$ & $(46.70)$ & $(49.97)$ & $(47.97)$ \\
\hline \multirow[t]{2}{*}{ Number of children } & 0.67 & 1.23 & 0.81 & 1.06 \\
\hline & $(0.99)$ & $(1.28)$ & $(1.03)$ & $(1.16)$ \\
\hline \multirow[t]{2}{*}{ Years since migration } & & 18.24 & & 19.69 \\
\hline & & $(10.25)$ & & $(11.70)$ \\
\hline Observations & 190,107 & 72,975 & 136,147 & 32,142 \\
\hline
\end{tabular}

Displayed are sample means and standard deviations within parentheses, calculated 2 years after start-up

employment performance. To reduce this bias, we will estimate regressions where we include individual fixed effects, $\alpha_{i}$, which control for all individual unobservable factors that are constant over time. In addition, the individual fixed effects implicitly control for selection out from self-employment that is related to time-constant factors. We estimate the following equation by OLS:

$Y_{i s j r t}=\alpha_{i}+X_{i t} \beta+\rho_{1} T_{i t}+\rho_{2} T_{i t}^{2}+\gamma_{s}+\theta_{j}+u_{r t}+\varepsilon_{i s j r t}$ where all variables are defined as above and $r$ refers to municipality. The year fixed effects are dropped in the individual fixed effects estimations, since it is not possible to include both age and year of observation simultaneously; they are perfectly correlated for each individual. We include the yearly local unemployment rate, $u_{r t}$, to reduce the bias from the omitted year dummies (Barth et al. 2004). For comparative reasons, we will estimate Eq. (1) without year fixed effects and controlling for the yearly local unemployment rate instead. This can help us 
evaluate the extent to which the results are affected by controlling for period effects by the local unemployment rate instead of year fixed effects. One drawback of including individual fixed effects in the model is that it precludes the inclusion of the indicator for being foreign born, and it is no longer possible to identify the initial performance gap at year of start-up. In the figures presented below, the plots based on regressions including individual fixed effects will have the starting values imposed as the sample means for each group, using predicted gaps estimated by Eq. (1). Our main purpose is to estimate differences in the return to experience in selfemployment between immigrants and natives. However, the performance gap at start-up is of interest especially for interpreting the results in terms of immigrant assimilation. The initial performance gap incorporates differences in observed individual characteristics (age, educational level, labour earnings, marital status, number of children, sector and region), but does not take into account potential selection into self-employment. If natives and immigrants entering self-employment differ in terms of, for instance, previous self-employment experience, talent or ability, this can bias the estimated difference in performance. In other words, the differences in levels should be interpreted with caution.

Although the individual fixed effects model is an improvement, it is still possible that the estimates of the returns to self-employment are biased. More specifically, omitted time-varying factors will lead to bias if they are correlated with experience and performance, and at the same time the strength and/or direction of the correlations vary for immigrants and natives. If, for instance, immigrants are more likely than natives to learn skills fast and/or become more motivated at the same time as they gain self-employment experience and this leads to better performance and/or affect the decision to remain in self-employment, we will overstate the returns to experience among immigrants. We control for several time-varying factors to reduce the risk of omitted variable bias, ${ }^{10}$ but with the data at hand we cannot rule out this possibility. Consequently, our estimates are not causal.

Table 3 shows the results for the regressions of yearly profit from self-employment. From column (1), it

\footnotetext{
$\overline{{ }^{10} \text { Time-varying }}$ control variables (such as e.g. sector) might be endogenous in the regressions. As a robustness test we have estimated the regressions without sector fixed effects and found that this had little impact on the results. These results are not displayed but are available from the author upon request.
}

emerges that women's profit increases by about $23 \%$ with one additional year of self-employment experience. The coefficient for the interaction between years in selfemployment and the immigrant indicator is not statistically significantly different from zero, implying that the yearly return to experience is similar for immigrant and native women. In column (2), the year fixed effects are omitted and the local unemployment rate is included; this has little effect on the results. When controlling for individual fixed effects in column (3), the returns to experience is reduced to about $5 \%$ for native women. It is noteworthy that the return to experience is statistically significantly higher for immigrant women in comparison to native women. Immigrant women gain about twice as much (9\%) as native women from an additional year of self-employment experience (column (3)).

The results for men show that an additional year of self-employment experience is associated with a $20 \%$ increase in profit among native men (columns (4) and (5)). Immigrant men have about $2 \%$ lower return to selfemployment experience compared to native men (column (4)), but this result is not robust to including the local unemployment rate instead of the year dummies (column (5)). In line with the results for women, the returns to experience among self-employed men are reduced when we control for time-constant individual factors in column (6). Native men gain about $3 \%$ and immigrant men $4 \%$ from an additional year of experience, and the estimate is statistically significantly larger for immigrants than for natives.

Among both men and women, it is likely that a large part of the observed returns to experience in columns (1), (2), (4) and (5) is because those with high ability, motivation and talent stay in selfemployment and the unsuccessful leave. However, when taking time-constant factors such as entrepreneurial ability into account in columns (3) and (6), experience still increases profit, and more for immigrants than for natives. We should keep in mind that time-varying variables could differ for immigrants and natives, and this could bias our estimates. The difference in the returns to experience between immigrants and natives could be due to immigrants learning business skills faster than natives and this allows immigrants to perform better and/or make them more likely than natives to stay in business. In other words, our estimates are not causal.

Moreover, the results in Table 3 show that experience is concavely related to profit. The individual 
Table 3 OLS regressions for yearly profit from self-employment

\begin{tabular}{|c|c|c|c|c|c|c|}
\hline \multirow[b]{2}{*}{ Variables } & \multicolumn{3}{|l|}{ Women } & \multicolumn{3}{|l|}{ Men } \\
\hline & $(1)$ & (2) & (3) & (4) & $(5)$ & $(6)$ \\
\hline Years in self-employment & $\begin{array}{l}0.233 * * * \\
(0.005)\end{array}$ & $\begin{array}{l}0.233 * * * \\
(0.005)\end{array}$ & $\begin{array}{l}0.047 * * * \\
(0.005)\end{array}$ & $\begin{array}{l}0.197 * * * \\
(0.004)\end{array}$ & $\begin{array}{l}0.201 * * * \\
(0.004)\end{array}$ & $\begin{array}{l}0.031 * * * \\
(0.004)\end{array}$ \\
\hline Immigrant $\times$ years in self-employment & $\begin{array}{l}0.003 \\
(0.011)\end{array}$ & $\begin{array}{l}0.014 \\
(0.011)\end{array}$ & $\begin{array}{l}0.045 * * * \\
(0.012)\end{array}$ & $\begin{array}{l}-0.021 * * * \\
(0.007)\end{array}$ & $\begin{array}{l}-0.001 \\
(0.007)\end{array}$ & $\begin{array}{l}0.013 * \\
(0.008)\end{array}$ \\
\hline Years in self-employment squared & $\begin{array}{l}-0.023 * * * \\
(0.001)\end{array}$ & $\begin{array}{l}-0.021 * * * \\
(0.001)\end{array}$ & $\begin{array}{l}-0.006 * * * \\
(0.001)\end{array}$ & $\begin{array}{l}-0.020 * * * \\
(0.001)\end{array}$ & $\begin{array}{l}-0.019 * * * \\
(0.001)\end{array}$ & $\begin{array}{l}-0.004 * * * \\
(0.001)\end{array}$ \\
\hline Immigrant $\times$ years in self-employment squared & $\begin{array}{l}-0.000 \\
(0.002)\end{array}$ & $\begin{array}{l}-0.002 \\
(0.002)\end{array}$ & $\begin{array}{l}-0.004^{* * * *} \\
(0.001)\end{array}$ & $\begin{array}{l}0.001 \\
(0.001)\end{array}$ & $\begin{array}{l}-0.001 \\
(0.001)\end{array}$ & $\begin{array}{l}-0.004 * * * \\
(0.001)\end{array}$ \\
\hline Individual fixed effects & No & No & Yes & No & No & Yes \\
\hline Year fixed effects & Yes & No & No & Yes & No & No \\
\hline Local unemployment rate & No & Yes & Yes & No & Yes & Yes \\
\hline$R$-squared & 0.126 & 0.123 & 0.054 & 0.127 & 0.120 & 0.059 \\
\hline Prediction at sample means & 4.831 & 4.831 & 4.831 & 5.166 & 5.166 & 5.166 \\
\hline Number of individuals & 57,632 & 57,632 & 57,632 & 90,572 & 90,572 & 90,572 \\
\hline Number of observations & 157,524 & 157,524 & 157,524 & 248,748 & 248,748 & 248,748 \\
\hline
\end{tabular}

Robust standard errors, clustered on individuals, in parentheses. Dependent variable is logarithm of yearly firm profit. All regressions include an indicator for being immigrant and controls for a quadratic function of age, education, marital status, number of children, income from wage-employment, and a quadratic function of years since migration for immigrants that is set to zero for natives. In addition, region and sector fixed effects are included. All control variables are interacted with the immigrant indicator

$* p<0.1 ; * * p<0.05 ; * * * p<0.01$

fixed effect estimates in columns (3) and (6) show that the coefficient for the square of years of selfemployment is negative for all groups and more strongly negative among immigrants. However, the impact of self-employment experience is larger for immigrant men and women than for their native counterparts for the full range of experience considered (1 to 8 years).

In addition to the results presented in Table 3, we have analysed how earnings from self-employment are related to experience. In general, the coefficient estimates point in the same direction as for profit but the differences in the returns to experience are not statistically significantly different for immigrants and natives. The results are presented in Table 5 and Fig. 6 in the Appendix.

In Fig. 1 the predicted profit from the regressions in Table 3 are plotted against years in self-employment. The graph to the left includes year fixed effects (columns (1) and (4)), and the graph to the right includes individual fixed effects (columns (3) and (6)). At startup, men have higher predicted profit than women, and natives have higher predicted profit than immigrants. With experience, all groups increase their profit. The graph without individual fixed effects shows a rather high return to experience. When including individual fixed effects, it appears that the returns to years in selfemployment decrease, but mainly among natives. It appears that both immigrant women's and immigrant men's profits approach those of their native counterparts as they become more experienced in self-employment. However, we must keep in mind that the initial gaps could be biased by omitted variables such as ability, motivation, talent and previous experience of self-employment. Should the initial native-immigrant profit gap be smaller (larger) than indicated by our estimates, immigrants might (never) surpass the profit level of natives.

Table 4 displays the regression results for yearly turnover. In line with the results for profit, turnover increases with about $19 \%$ for each additional year in self-employment (columns (1), (2), (4) and (5)). Immigrant men have around 3\% lower returns to experience than native men (columns (4) and (5)), but there appear 

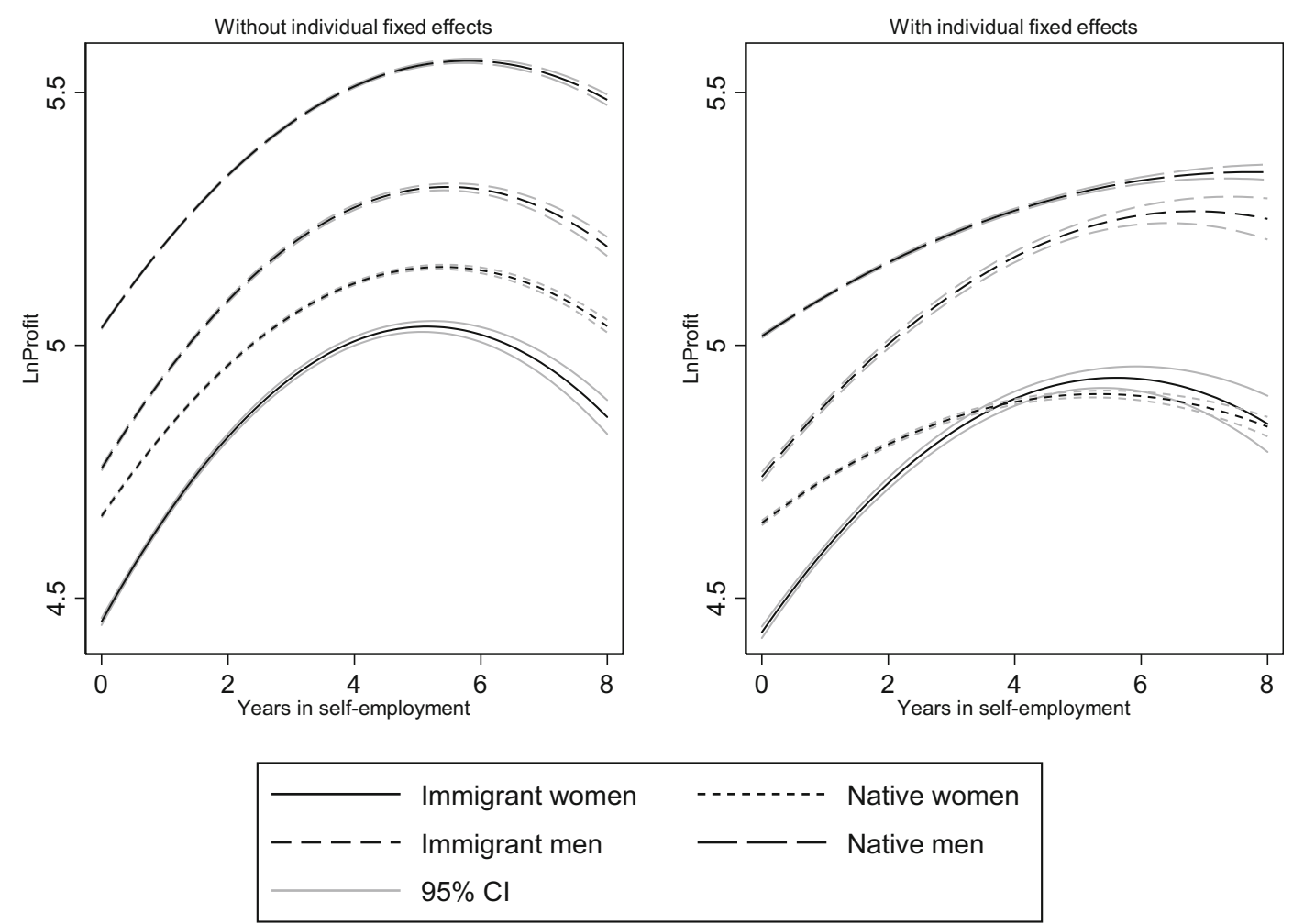

Fig. 1 Predicted yearly profit by years in self-employment

to be no differences among women (columns (1) and (2)). The coefficient for years in self-employment square is negative independently of specification, indicating that the impact of self-employment experience is reduced as experience increases. If time-constant individual factors are taken into account, the increase in turnover from having longer business experience decreases to about $4 \%$ for both men and women (columns (3) and (6)). The individual fixed effects estimations for firm turnover provide no evidence that the return to years in self-employment differs for immigrants and natives.

Figure 2 displays the predicted turnover based on the regressions presented in Table 4 . The left panel displays estimates without individual fixed effects and it appears that immigrants at start-up have higher turnover than natives, and that the differences are reduced as experience increases. However, when individual fixed effects are included, the gaps observed at start-up are of about similar magnitude after 8 years of experience. This is in contrast to the results for profit, where the initial gaps between immigrants and natives are substantially smaller 8 years after start-up.

To sum up, the results for the performance measures indicate that immigrants gain more profit than natives do from longer self-employment experience. It is also noteworthy that failing to incorporate time-invariant individual factors severely biases the results. First, the estimate of the return to years in self-employment is reduced substantially when individual fixed effects are added to the model. Second, some of the estimates without individual fixed effects misleadingly indicate that immigrant men have lower returns to experience than do native men. This indicates that individuals who stay in selfemployment are positively selected-e.g. have higher ability and knowledge of how to generate profitable firms than those leaving - and that the selection effects are stronger for natives than for immigrants. All in all, immigrant business owners seem to benefit more than native business owners from having learnt the relevant skills for successful self-employment. It is possible that immigrants are more restricted than natives by lack of business experience when they start their firms. As immigrants gain self-employment experience they might acquire more skills necessary for selfemployment than natives do because immigrants improve their proficiency in the host country language and develop their understanding of laws and regulations. In addition, gaining experience might reduce problems 
Table 4 OLS regressions for yearly firm turnover

\begin{tabular}{|c|c|c|c|c|c|c|}
\hline \multirow[b]{2}{*}{ Variables } & \multicolumn{3}{|l|}{ Women } & \multicolumn{3}{|l|}{ Men } \\
\hline & (1) & $(2)$ & (3) & (4) & $(5)$ & (6) \\
\hline Years in self-employment & $\begin{array}{l}0.198 * * * \\
(0.005)\end{array}$ & $\begin{array}{l}0.198 * * * \\
(0.005)\end{array}$ & $\begin{array}{l}0.038 \text { *** } \\
(0.005)\end{array}$ & $\begin{array}{l}0.185^{* * *} \\
(0.004)\end{array}$ & $\begin{array}{l}0.187 * * * \\
(0.004)\end{array}$ & $\begin{array}{l}0.049 * * * \\
(0.004)\end{array}$ \\
\hline Immigrant $\times$ years in self-employment & $\begin{array}{l}-0.009 \\
(0.011)\end{array}$ & $\begin{array}{l}-0.001 \\
(0.011)\end{array}$ & $\begin{array}{l}0.011 \\
(0.010)\end{array}$ & $\begin{array}{l}-0.038 * * * \\
(0.007)\end{array}$ & $\begin{array}{l}-0.024 * * * \\
(0.007)\end{array}$ & $\begin{array}{l}-0.009 \\
(0.007)\end{array}$ \\
\hline Years in self-employment squared & $\begin{array}{l}-0.020^{* * * *} \\
(0.001)\end{array}$ & $\begin{array}{l}-0.018^{* * *} \\
(0.001)\end{array}$ & $\begin{array}{l}-0.004 * * * \\
(0.001)\end{array}$ & $\begin{array}{l}-0.020^{* * *} \\
(0.001)\end{array}$ & $\begin{array}{l}-0.018 * * * \\
(0.001)\end{array}$ & $\begin{array}{l}-0.004 * * * \\
(0.000)\end{array}$ \\
\hline Immigrant $\times$ years in self-employment squared & $\begin{array}{l}-0.001 \\
(0.002)\end{array}$ & $\begin{array}{l}-0.003 \\
(0.002)\end{array}$ & $\begin{array}{l}-0.002 * \\
(0.001)\end{array}$ & $\begin{array}{l}0.001 \\
(0.001)\end{array}$ & $\begin{array}{l}0.000 \\
(0.001)\end{array}$ & $\begin{array}{l}-0.002^{* * * *} \\
(0.001)\end{array}$ \\
\hline Individual fixed effects & No & No & Yes & No & No & Yes \\
\hline Year fixed effects & Yes & No & No & Yes & No & No \\
\hline Local unemployment rate & No & Yes & Yes & No & Yes & Yes \\
\hline$R$-squared & 0.212 & 0.209 & 0.057 & 0.182 & 0.176 & 0.074 \\
\hline Prediction at sample means & 5.823 & 5.823 & 5.823 & 6.263 & 6.263 & 6.263 \\
\hline Number of individuals & 60,005 & 60,005 & 60,005 & 93,235 & 93,235 & 93,235 \\
\hline Number of observations & 165,075 & 165,075 & 165,075 & 258,278 & 258,278 & 258,278 \\
\hline
\end{tabular}

Robust standard errors, clustered on individuals, in parentheses. Dependent variable is logarithm of yearly firm turnover. All regressions include an indicator for being immigrant and controls for a quadratic function of age, education, marital status, number of children, income from wage-employment, and a quadratic function of years since migration for immigrants that is set to zero for natives. In addition, region and sector fixed effects are included. All control variables are interacted with the immigrant indicator

$* p<0.1 ; * * p<0.05 ; * * * p<0.01$

of attaining capital that immigrants face when they start a business, making their profits increase at a faster rate than among natives.

\subsection{Job creation among the self-employed}

From society's point of view, not only is it important that businesses generate income and are profitable, but that they also have the potential to generate jobs for others. Therefore, we will study hiring decisions among immigrant and native business owners and how these change with the length of self-employment. We will estimate a linear probability model for the likelihood of having employees with the same specifications as described in Eqs. (1) and (2). The reason for not using a logit or probit specification is that including individual fixed effects, in addition to sector fixed effects and region fixed effects, results in a separation problem: that success or failure is entirely predicted by the included control variables for a large share of the observations (e.g. Zorn 2005). Only the observations for which the probability of having employees is not entirely predicted by the control variables can be used to calculate marginal effects, which then will not be representative for the full sample.

The results from the regressions of the likelihood of having employees are displayed in Table 5 . The predicted probability of having employees (evaluated at the sample means) is about $12 \%$ for women and $15 \%$ for men. With an additional year of self-employment this probability increases by 1 to 2 percentage points, independently of which specification and group (women or men) we consider. Among women, the regression results do not indicate that the rate at which the probability of having employees increases with experience is different for immigrants and natives (columns (1) to (3)). For men, the results without individual fixed effects in columns (4) and (5) indicate that the probability of having employees increases more for immigrants than for natives as they gain an additional year of experience. However, when individual fixed effects are controlled for in column (6) there is no longer any statistically significant difference in the returns to experience between immigrant and native men. It appears that the coefficient for years in self-employment square is negative in all specification, implying that the influence of 

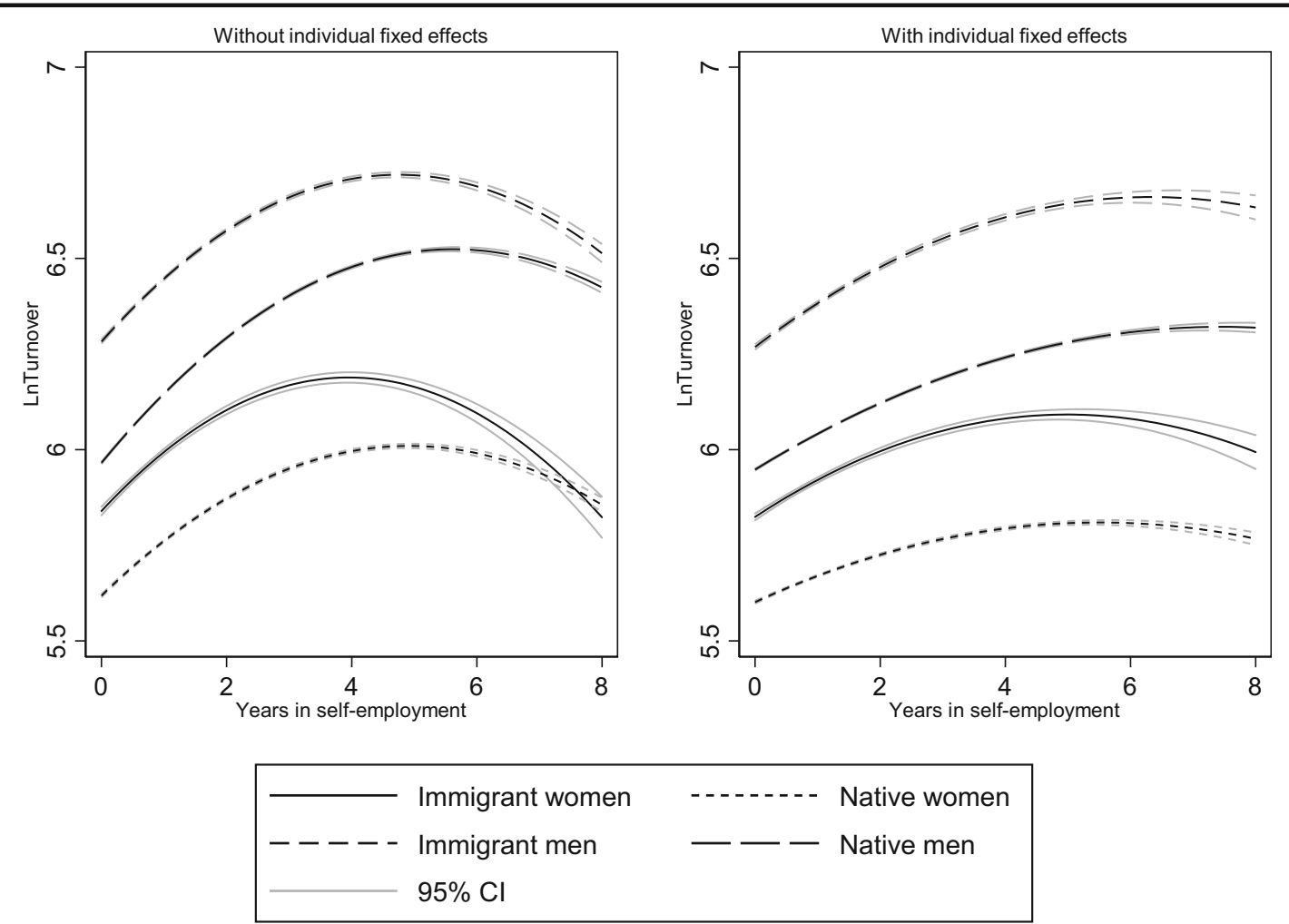

Fig. 2 Predicted yearly turnover by years in self-employment

self-employment experience is less when more experience has been acquired.

Figure 3 displays the predicted likelihood of having employees calculated from the regressions presented in Table 5. It appears that both immigrant women and men have a higher probability of having employees than their native counterparts, independently of how much selfemployment experience they had. When including individual fixed effects in the estimations, the gaps in the predicted probability between immigrants and natives increase or remain the same over all 8 years.

We have also considered an additional outcome for job creation: the firm's number of employees. These results are presented in Table 7 and Fig. 7 in the Appendix. In general, the results for number of employees are in line with the presented results for the likelihood of having employees.

In conclusion, the results show that the likelihood of having employees and the number of employees increase with experience and in a similar magnitude for immigrants and natives. Comparing the results with and without individual fixed effects, it appears that not controlling for individual fixed effects would lead to the misleading conclusion that experience has a larger effect on immigrant men's likelihood of having employees in comparison to native men. This is in contrast to the result for profit and turnover. It is possible that immigrant business owners who manage to survive in selfemployment are those who entered market segments where production requires many employees but where prospects for high profits are low. ${ }^{11}$ The individual fixed effect model incorporates differences in the choice of market segment-as long as the decision does not change over time - and this might explain the contradictory result for performance and job creation.

\subsection{Heterogeneity}

Previous research has shown that self-employment performance among immigrants in Sweden depends on whether they are from European or non-European coun-

\footnotetext{
${ }^{11}$ Another explanation is that immigrant business owners have lower productivity. As a robustness check we have analysed a measure that could approximate productivity: income from sales divided by number of employees. The results show that productivity increase with years in self-employment and that the effect is not statistically significantly different for native and immigrant business owners. The results are not displayed, but are available from the author upon request.
} 
Table 5 OLS regressions for probability of having employees at firm

\begin{tabular}{|c|c|c|c|c|c|c|}
\hline \multirow[b]{2}{*}{ Variables } & \multicolumn{3}{|l|}{ Women } & \multicolumn{3}{|l|}{ Men } \\
\hline & (1) & (2) & (3) & (4) & $(5)$ & (6) \\
\hline Years in self-employment & $\begin{array}{l}1.625 * * * \\
(0.132)\end{array}$ & $\begin{array}{l}1.666^{* * * *} \\
(0.129)\end{array}$ & $\begin{array}{l}0.933 * * * \\
(0.135)\end{array}$ & $\begin{array}{l}1.671 * * * \\
(0.121)\end{array}$ & $\begin{array}{l}1.787 * * * \\
(0.119)\end{array}$ & $\begin{array}{l}1.295 * * * \\
(0.128)\end{array}$ \\
\hline Immigrant $\times$ years in self-employment & $\begin{array}{l}0.097 \\
(0.354)\end{array}$ & $\begin{array}{l}0.282 \\
(0.347)\end{array}$ & $\begin{array}{l}-0.022 \\
(0.361)\end{array}$ & $\begin{array}{l}1.242 * * * \\
(0.274)\end{array}$ & $\begin{array}{l}1.503 * * * \\
(0.270)\end{array}$ & $\begin{array}{l}0.396 \\
(0.300)\end{array}$ \\
\hline Years in self-employment squared & $\begin{array}{l}-0.127^{* * *} \\
(0.024)\end{array}$ & $\begin{array}{l}-0.116^{* * * *} \\
(0.023)\end{array}$ & $\begin{array}{l}-0.061 * * * \\
(0.019)\end{array}$ & $\begin{array}{l}-0.162^{* * *} \\
(0.023)\end{array}$ & $\begin{array}{l}-0.139 * * * \\
(0.022)\end{array}$ & $\begin{array}{l}-0.096^{* * * *} \\
(0.019)\end{array}$ \\
\hline Immigrant $\times$ years in self-employment squared & $\begin{array}{l}-0.122^{*} \\
(0.065)\end{array}$ & $\begin{array}{l}-0.098 \\
(0.063)\end{array}$ & $\begin{array}{l}-0.033 \\
(0.051)\end{array}$ & $\begin{array}{l}-0.267 * * * \\
(0.049)\end{array}$ & $\begin{array}{l}-0.213 * * * \\
(0.048)\end{array}$ & $\begin{array}{l}-0.180 * * * \\
(0.042)\end{array}$ \\
\hline Individual fixed effects & No & No & Yes & No & No & Yes \\
\hline Year fixed effects & Yes & No & No & Yes & No & No \\
\hline Local unemployment rate & No & Yes & Yes & No & Yes & Yes \\
\hline$R$-squared & 0.114 & 0.112 & 0.021 & 0.122 & 0.116 & 0.034 \\
\hline Predicted probability at sample means & 11.59 & 11.59 & 11.59 & 15.46 & 15.46 & 15.46 \\
\hline Number of individuals & 60,972 & 60,972 & 60,972 & 94,676 & 94,676 & 94,676 \\
\hline Number of observations & 168,289 & 168,289 & 168,289 & 263,082 & 263,082 & 263,082 \\
\hline
\end{tabular}

Robust standard errors, clustered on individuals, in parentheses. All regressions include an indicator for being immigrant and controls for a quadratic function of age, education, marital status, number of children, income from wage-employment, and a quadratic function of years since migration for immigrants that is set to zero for natives. In addition, region and sector fixed effects are included. All control variables are interacted with the immigrant indicator. The coefficients are reported in percentage points

$* p<0.1 ; * * p<0.05 ; * * * p<0.01$

tries (e.g. Andersson Joona 2011; Hammarstedt 2006; Andersson and Hammarstedt 2011). To test for this, we have estimated the regressions as specified in Eq. (2) but distinguished European from non-European immigrants. The predicted profit, turnover and probability of having employees are plotted separately for European immigrants, non-European immigrants and natives. Figure 4 shows the predictions for women and Fig. 5 displays men's predicted outcomes. In terms of profit, women from non-European countries earn the least profit to start with but experience a steeper growth than natives and European immigrants as they gain experience. However, after 8 years, there are no statistically significant differences between the groups among women. Similarly, profit is lowest for men from nonEuropean countries at the start-up of the firm. Male business owners from non-European countries increase their profit more than the other groups as they gain experience.

Furthermore, the turnover and the probability of having employees are much higher for non-European immigrants than for European immigrant and natives, regardless of gender. The firms of non-European immigrants continue to be bigger and to be more likely to have employees as business experience increases.

In addition, we have tested for heterogeneous effects across individuals based on their age and years since migration. ${ }^{12}$ We split the sample by the median age (43 years), and by the median years since migration for immigrants (16 years). In general, persons younger than 43 tend to have higher returns to selfemployment experience than persons older than 43 . This could be because older people have already attained the relevant experience in other ways. Moreover, we find that having experience from selfemployment has a larger impact on the outcomes of immigrants who resided in Sweden for more than 16 years. For more recent arrivals, it is possible that other experience is relevant, such as host countryspecific knowledge such as proficiency in the language.

\footnotetext{
${ }^{12}$ The results are available from the author upon request.
} 

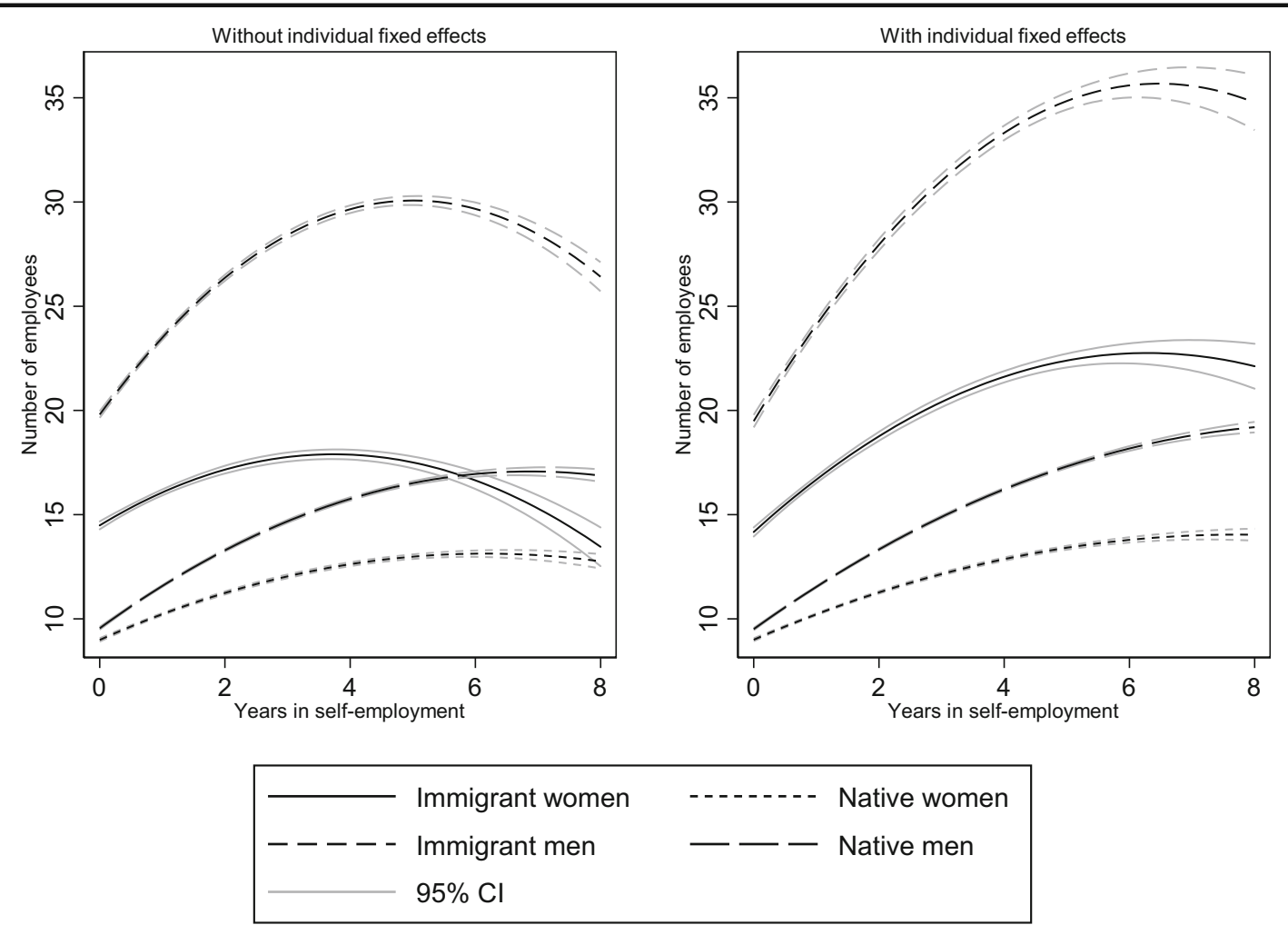

Fig. 3 Predicted probability of having employees at firm by years in self-employment

\section{Conclusions}

The large increase of migration to many countries has brought the labour market integration of immigrants to the top of the agenda. Increasing the selfemployment rates has been suggested as one solution to poor labour market outcomes among the foreign born. Whether this will be successful or not depends on how well immigrants perform in self-employment. In this paper, we study selfemployment performance and job creation among immigrants and natives in Sweden. We focus on the ways in which performance and job creation are related to self-employment experience. Previous research has indicated that immigrants face difficulties when starting their businesses but is still unknown whether difficulties recede as the business owner gains more experience.

The results show that profits from selfemployment are higher for natives than for immigrants and that men gain more from their business than do women. Men also tend to have higher turnover in their firms than women, and the turnover is higher in firms owned by immigrants than in those owned by natives. These results are in line with the findings in previous studies for Sweden (e.g. Andersson Joona 2011; Hammarstedt 2006; Andersson and Hammarstedt 2011). In terms of job creation, it seems that immigrants' firms, and especially those owned by non-European immigrants, have more employees at their firms on average and are more likely to have employees. We control for several individual characteristics, but omitted factors such as ability, motivation and experience could imply that we over- or underestimated the differences in self-employment performance between immigrant and native business owners.

Being more experienced in self-employment is positively related to self-employment performance in the sense that it increases profits, earnings, turnover, the number of employees, and the likelihood of having employees. Interestingly, experience seems to be more valuable for immigrants than for natives. More specifically, as immigrants gain selfemployment experience their profit increases more than among natives. Turnover and the likelihood of having employees increase with experience and in a similar magnitude for immigrants and natives. Our 

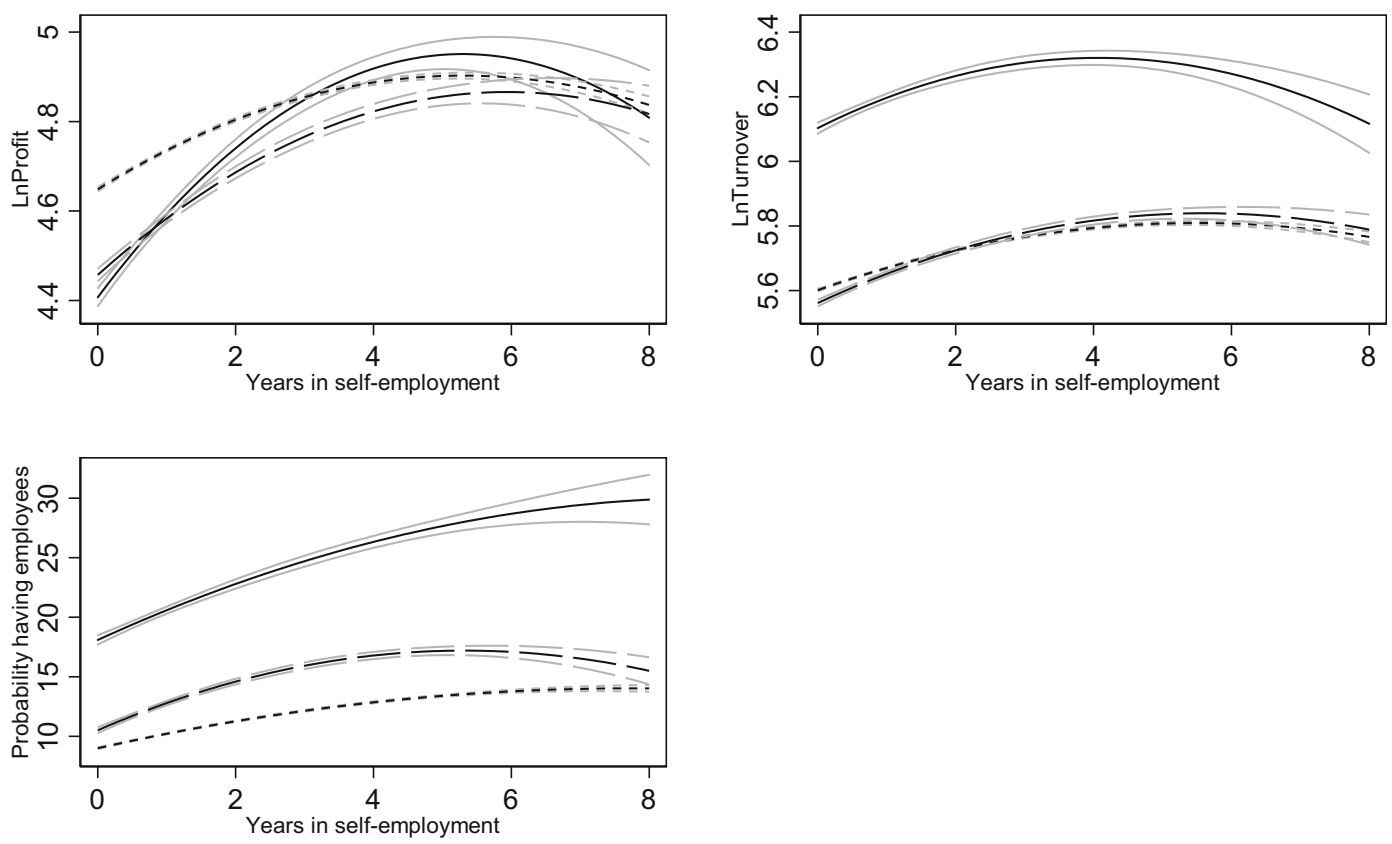

\begin{tabular}{|lll|}
\hline- & Immigrant women, Non-European $\quad-\quad-\quad$ Immigrant women, European \\
$-\ldots-1$ & Native women & $95 \% \mathrm{Cl}$
\end{tabular}

Fig. 4 Predicted outcomes by immigrant group. Women

results highlight the importance of taking into account that individuals who leave self-employment might be different from those who stay; the most successful might be more likely to remain in selfemployment. Comparing the results with and without individual fixed effects, it appears that neglecting to control for individual fixed effects fixed effects lead to several misleading conclusions. First, the coefficient for self-employment experience is biased downwards for immigrant women in the profit regression, and for immigrant men in the regressions of profit and turnover. The results without individual fixed effects misleadingly indicate that immigrant men have lower and immigrant women similar returns to experience as their native counterparts. Second, the coefficient for selfemployment experience is biased upwards for immigrant men in the regression of the likelihood of having employees, which leads to the wrong conclusion that more experience increases the likelihood of having employees more for immigrant men than for native men. It is possible that the disparities in the results are driven by the fact that immigrant business owners who manage to survive in selfemployment are those who entered market segments where production requires many employees but where prospects for high profits are low. The individual fixed effect model controls for choice of market segment - as long as the decision does not change over time - and reduces the bias from selection effects. Although adding individual fixed effects to the model reduces the bias from omitted time-constant factors other time-varying factors could bias the coefficient for years in selfemployment both upwards and downwards.

Previous research based on cross-sectional data has found both negative and positive correlations between experience from being self-employed and performance as self-employed (Burke et al. 2002; Shane 2003; Van der Sluis et al. 2008). Our estimates that incorporate individual fixed effects point in the direction that self-employment experience has a positive effect on the performance as selfemployed. Moreover, Constant et al. (2007) use cross-sectional data and find that experience is positively correlated to immigrant men's earnings and 

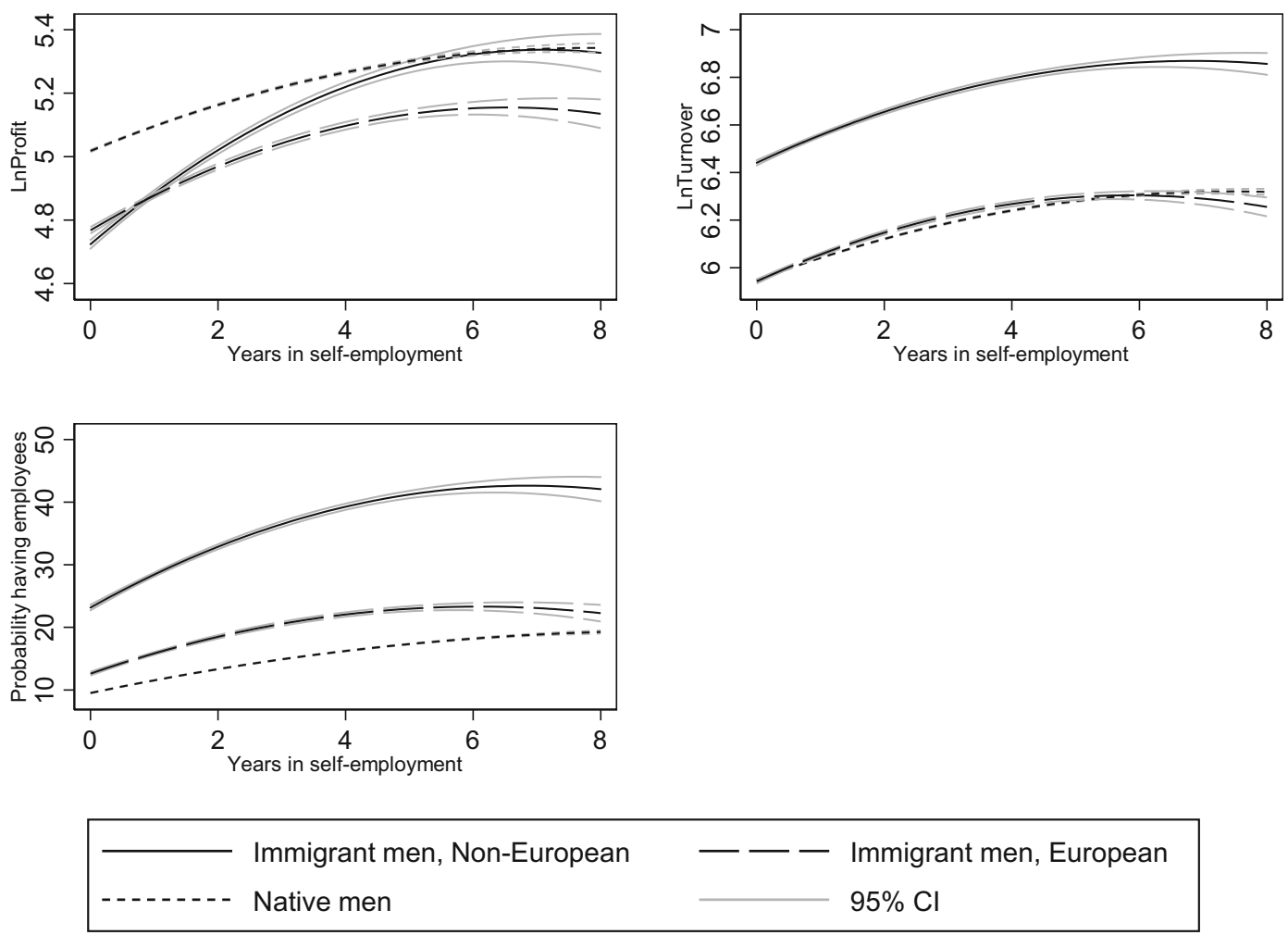

Fig. 5 Predicted outcomes by immigrant group. Men

uncorrelated to native men's earnings in Germany. This is in contrast to our results that indicate that both immigrant and native men have positive returns to experience but are consistent with our finding that the returns are higher for immigrant men. In the paper most closely related to ours, Lofstrom (2011) finds that the earnings of low-skilled self-employed immigrant men (women) grow faster (slower) than for native men (women) with years in business. In contrast, our results point in the direction that both immigrant women and immigrant men have higher returns to experience than their native counterparts.

The way in which firms contribute to job creation is a central aspect of self-employment. In this paper, we add to the scarce literature on job creation and focus on the differences between immigrants and natives. The results show that immigrant firms have more employees than native firms and remain larger when they have been in business for several years. It is possible that this is because immigrants are running businesses in more labour-intensive production and/or benefit from recruiting co-ethnics that they pay below-market wages. At the same time, it seems that immigrants initially face obstacles that hinder them from gaining large profits from their firms. To conclude on whether policies intended to lower unemployment and/or increase labour market attachment among the foreign born should aim at stimulating immigrant self-employment more research on the job-seekers that the immigrant firms hire is needed. Especially since recent research indicates that entrepreneurs to a large extent do not hire people who were unemployed or outside the labour force (see e.g. Åstebro and Tåg 2017). It would be fruitful for future research to investigate if immigrant and native firms differ in the extent to which they create jobs for persons who were unemployed or outside the labour force.

Funding Financial support from the project "Obstacles and possibilities for self-employment among immigrants in the retail and trade sector" funded by the Jan Wallander and Tom Hedelius Foundation is greatly appreciated.

\section{Compliance with ethical standards}

Conflict of interest The author declares that she has no conflict of interest. 


\section{Appendix}

Table 6 OLS regressions for yearly self-employment earnings

\begin{tabular}{|c|c|c|c|c|c|c|}
\hline \multirow[b]{2}{*}{ Variables } & \multicolumn{3}{|l|}{ Women } & \multicolumn{3}{|l|}{ Men } \\
\hline & (1) & (2) & (3) & (4) & $(5)$ & (6) \\
\hline Years in self-employment & $\begin{array}{l}0.313 * * * \\
(0.005)\end{array}$ & $\begin{array}{l}0.326 \text { *** } \\
(0.005)\end{array}$ & $\begin{array}{l}0.106^{* * * *} \\
(0.006)\end{array}$ & $\begin{array}{l}0.281 * * * \\
(0.004)\end{array}$ & $\begin{array}{l}0.291 * * * \\
(0.004)\end{array}$ & $\begin{array}{l}0.094 * * * \\
(0.005)\end{array}$ \\
\hline Immigrant $\times$ years in self-employment & $\begin{array}{l}-0.038 * * * \\
(0.012)\end{array}$ & $\begin{array}{l}-0.026^{* * *} \\
(0.011)\end{array}$ & $\begin{array}{l}0.014 \\
(0.014)\end{array}$ & $\begin{array}{l}-0.034 * * * \\
(0.007)\end{array}$ & $\begin{array}{l}-0.014^{* * *} \\
(0.007)\end{array}$ & $\begin{array}{l}0.012 \\
(0.009)\end{array}$ \\
\hline Years in self-employment squared & $\begin{array}{l}-0.029 * * * \\
(0.001)\end{array}$ & $\begin{array}{l}-0.029 * * * \\
(0.001)\end{array}$ & $\begin{array}{l}-0.013 * * * \\
(0.001)\end{array}$ & $\begin{array}{l}-0.027 * * * \\
(0.001)\end{array}$ & $\begin{array}{l}-0.026^{* * * *} \\
(0.001)\end{array}$ & $\begin{array}{l}-0.012^{* * *} \\
(0.001)\end{array}$ \\
\hline Immigrant $\times$ years in self-employment squared & $\begin{array}{l}0.005 * * * \\
(0.002)\end{array}$ & $\begin{array}{l}0.003 * \\
(0.002)\end{array}$ & $\begin{array}{l}-0.002 \\
(0.002)\end{array}$ & $\begin{array}{l}0.003 * * \\
(0.001)\end{array}$ & $\begin{array}{l}0.001 \\
(0.001)\end{array}$ & $\begin{array}{l}-0.004 * * * \\
(0.001)\end{array}$ \\
\hline Individual fixed effects & No & No & Yes & No & No & Yes \\
\hline Year fixed effects & Yes & No & No & Yes & No & No \\
\hline Local unemployment rate & No & Yes & Yes & No & Yes & Yes \\
\hline$R$-squared & 0.160 & 0.154 & 0.079 & 0.162 & 0.155 & 0.088 \\
\hline Prediction at sample means & 6.572 & 6.572 & 6.572 & 6.913 & 6.913 & 6.913 \\
\hline Number of individuals & 59,718 & 59,718 & 59,718 & 93,388 & 93,388 & 93,388 \\
\hline Number of observations & 165,596 & 165,596 & 165,596 & 260,054 & 260,054 & 260,054 \\
\hline
\end{tabular}

Robust standard errors, clustered on individuals, in parentheses. Dependent variable is logarithm of yearly self-employment earnings. All regressions include an indicator for being immigrant and controls for a quadratic function of age, education, marital status, number of children, income from wage-employment, and a quadratic function of years since migration for immigrants that is set to zero for natives. In addition, region and sector fixed effects are included. All control variables are interacted with the immigrant indicator

$* p<0.1 ; * * p<0.05 ; * * * p<0.01$ 
Table 7 OLS regressions for number of employees at firm

\begin{tabular}{|c|c|c|c|c|c|c|}
\hline \multirow[b]{2}{*}{ Variables } & \multicolumn{3}{|l|}{ Women } & \multicolumn{3}{|l|}{ Men } \\
\hline & (1) & (2) & (3) & (4) & $(5)$ & $(6)$ \\
\hline Years in self-employment & $\begin{array}{l}0.023 * * \\
(0.009)\end{array}$ & $\begin{array}{l}0.024 * * * \\
(0.007)\end{array}$ & $\begin{array}{l}0.010 * * \\
(0.005)\end{array}$ & $\begin{array}{l}0.065^{* * *} \\
(0.019)\end{array}$ & $\begin{array}{l}0.069 * * * \\
(0.018)\end{array}$ & $\begin{array}{l}0.049 * * * \\
(0.016)\end{array}$ \\
\hline Immigrant $\times$ years in self-employment & $\begin{array}{l}0.012 \\
(0.014)\end{array}$ & $\begin{array}{l}0.011 \\
(0.013)\end{array}$ & $\begin{array}{l}0.008 \\
(0.011)\end{array}$ & $\begin{array}{l}-0.010 \\
(0.021)\end{array}$ & $\begin{array}{l}-0.009 \\
(0.020)\end{array}$ & $\begin{array}{l}-0.036 \\
(0.022)\end{array}$ \\
\hline Years in self-employment squared & $\begin{array}{l}-0.001 \\
(0.001)\end{array}$ & $\begin{array}{l}-0.001 \\
(0.001)\end{array}$ & $\begin{array}{l}0.000 \\
(0.001)\end{array}$ & $\begin{array}{l}-0.007 * * * \\
(0.003)\end{array}$ & $\begin{array}{l}-0.007 * * * \\
(0.003)\end{array}$ & $\begin{array}{l}-0.003 \\
(0.002)\end{array}$ \\
\hline Immigrant $\times$ years in self-employment squared & $\begin{array}{l}-0.004^{* *} \\
(0.002)\end{array}$ & $\begin{array}{l}-0.003 * \\
(0.002)\end{array}$ & $\begin{array}{l}-0.002 \\
(0.002)\end{array}$ & $\begin{array}{l}0.002 \\
(0.003)\end{array}$ & $\begin{array}{l}0.004 \\
(0.003)\end{array}$ & $\begin{array}{l}0.001 \\
(0.003)\end{array}$ \\
\hline Individual fixed effects & No & No & Yes & No & No & Yes \\
\hline Year fixed effects & Yes & No & No & Yes & No & No \\
\hline Local unemployment rate & No & Yes & Yes & No & Yes & Yes \\
\hline$R$-squared & 0.009 & 0.009 & 0.001 & 0.010 & 0.010 & 0.003 \\
\hline Prediction at sample means & 0.24 & 0.24 & 0.24 & 0.34 & 0.34 & 0.34 \\
\hline Number of individuals & 60,972 & 60,972 & 60,972 & 94,676 & 94,676 & 94,676 \\
\hline Number of observations & 168,289 & 168,289 & 168,289 & 263,082 & 263,082 & 263,082 \\
\hline
\end{tabular}

Robust standard errors, clustered on individuals, in parentheses. All regressions include an indicator for being immigrant and controls for a quadratic function of age, education, marital status, number of children, income from wage-employment, and a quadratic function of years since migration for immigrants that is set to zero for natives. In addition, region and sector fixed effects are included. All control variables are interacted with the immigrant indicator

$* p<0.1 ; * * p<0.05 ; * * * p<0.01$ 
Table 8 OLS performance regressions with non-logarithmic outcomes

\begin{tabular}{|c|c|c|c|c|c|c|c|c|}
\hline \multirow[b]{3}{*}{ Variables } & \multicolumn{4}{|l|}{ Profit } & \multicolumn{4}{|l|}{ Turnover } \\
\hline & \multicolumn{2}{|l|}{ Women } & \multicolumn{2}{|l|}{ Men } & \multicolumn{2}{|l|}{ Women } & \multicolumn{2}{|l|}{ Men } \\
\hline & $(5)$ & (6) & (7) & (8) & (9) & $(10)$ & (11) & (12) \\
\hline Years in self-employment & $\begin{array}{l}36.491 * * * \\
(2.847)\end{array}$ & $\begin{array}{l}11.414 * * * \\
(2.930)\end{array}$ & $\begin{array}{l}56.276^{* * * *} \\
(7.698)\end{array}$ & $\begin{array}{l}10.919 * \\
(5.639)\end{array}$ & $\begin{array}{l}64.113 * * * \\
(20.804)\end{array}$ & $\begin{array}{l}15.290^{*} \\
(8.626)\end{array}$ & $\begin{array}{l}139.047 * * * \\
(28.623)\end{array}$ & $\begin{array}{l}56.031 * * \\
(22.065)\end{array}$ \\
\hline Immigrant $\times$ years in self- employment & $\begin{array}{l}-4.233 \\
(3.799)\end{array}$ & $\begin{array}{l}-1.221 \\
(3.644)\end{array}$ & $\begin{array}{l}-27.096^{* * *} \\
(7.886)\end{array}$ & $\begin{array}{l}-4.511 \\
(5.814)\end{array}$ & $\begin{array}{l}37.191 \\
(31.491)\end{array}$ & $\begin{array}{l}15.609 \\
(16.021)\end{array}$ & $\begin{array}{l}-5.757 \\
(36.601)\end{array}$ & $\begin{array}{l}3.047 \\
(25.692)\end{array}$ \\
\hline Years in self-employment squared & $\begin{array}{l}-4.000 * * * \\
(0.426)\end{array}$ & $\begin{array}{l}-1.011 * * * \\
(0.356)\end{array}$ & $\begin{array}{l}-7.102 * * * \\
(1.017)\end{array}$ & $\begin{array}{l}-0.588 \\
(0.664)\end{array}$ & $\begin{array}{l}-6.409^{* *} \\
(2.760)\end{array}$ & $\begin{array}{l}0.019 \\
(2.369)\end{array}$ & $\begin{array}{l}-16.496^{* * *} \\
(3.903)\end{array}$ & $\begin{array}{l}-2.198 \\
(3.238)\end{array}$ \\
\hline $\begin{array}{l}\text { Immigrant } \times \text { years in self- employment } \\
\text { squared }\end{array}$ & $\begin{array}{l}0.292 \\
(0.588)\end{array}$ & $\begin{array}{l}-0.344 \\
(0.466)\end{array}$ & $\begin{array}{l}3.695 * * * \\
(1.074)\end{array}$ & $\begin{array}{l}-0.140 \\
(0.694)\end{array}$ & $\begin{array}{l}-8.371 * \\
(4.348)\end{array}$ & $\begin{array}{l}-5.391 * \\
(2.962)\end{array}$ & $\begin{array}{l}-2.109 \\
(5.028)\end{array}$ & $\begin{array}{l}-6.018 * \\
(3.643)\end{array}$ \\
\hline Individual fixed effects & No & Yes & No & Yes & No & Yes & No & Yes \\
\hline Year fixed effects & Yes & No & Yes & No & Yes & No & Yes & No \\
\hline$R$-squared & 0.015 & 0.005 & 0.016 & 0.009 & 0.008 & 0.001 & 0.008 & 0.001 \\
\hline Number of individuals & 60,972 & 60,972 & 94,676 & 94,676 & 60,972 & 60,972 & 94,676 & 94,676 \\
\hline Observations & 168,289 & 168,289 & 263,082 & 263,082 & 168,289 & 168,289 & 263,082 & 263,082 \\
\hline
\end{tabular}

Robust standard errors, clustered on individuals, in parentheses. All regressions include an indicator for being immigrant and controls for a quadratic function of age, education, marital status, number of children, income from wage-employment, and a quadratic function of years since migration for immigrants that is set to zero for natives. In addition, region and sector fixed effects are included. All control variables are interacted with the immigrant indicator

$* p<0.1 ; * * p<0.05 ; * * * p<0.01$ 

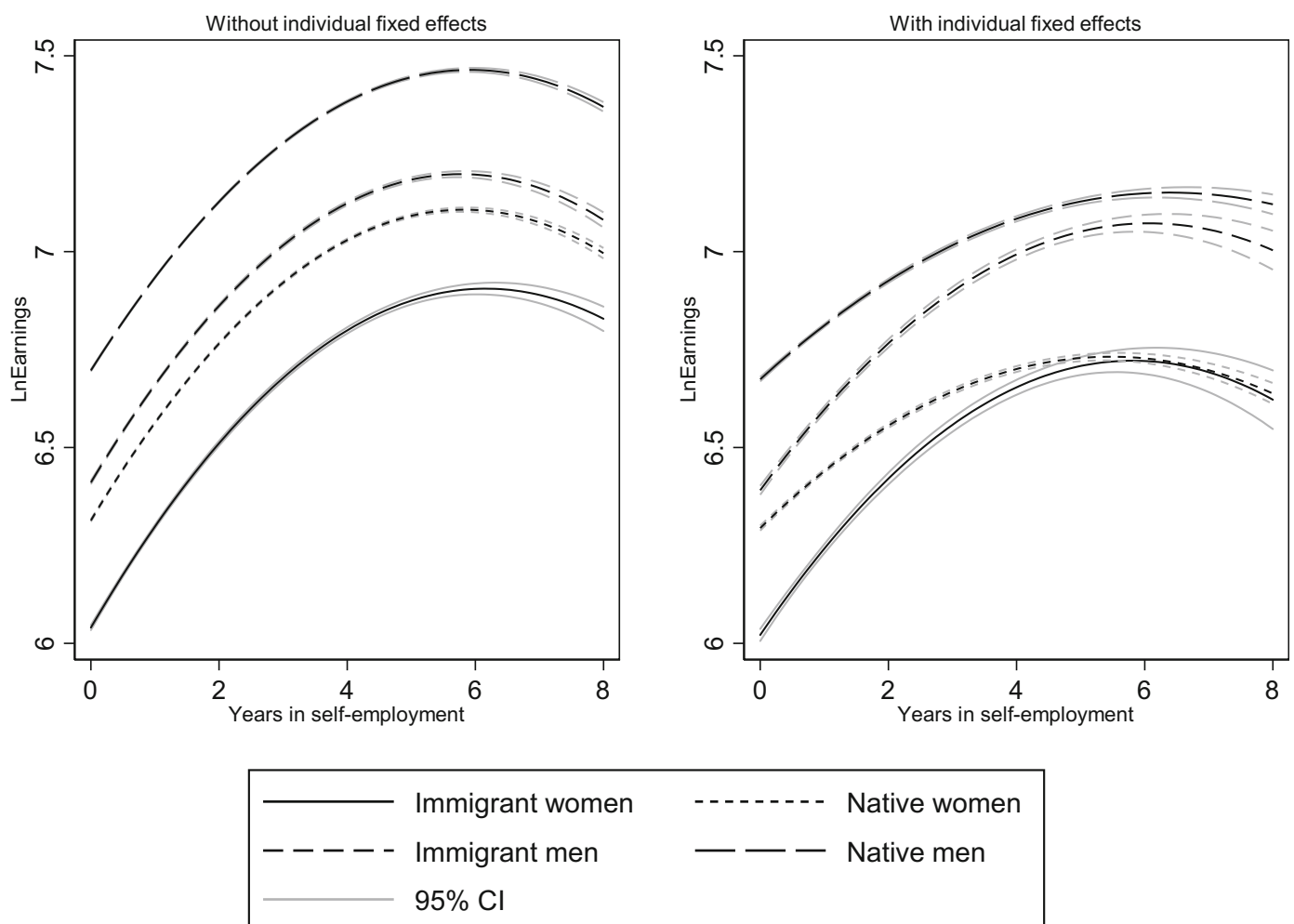

Fig. 6 Predicted yearly earnings by years in self-employment
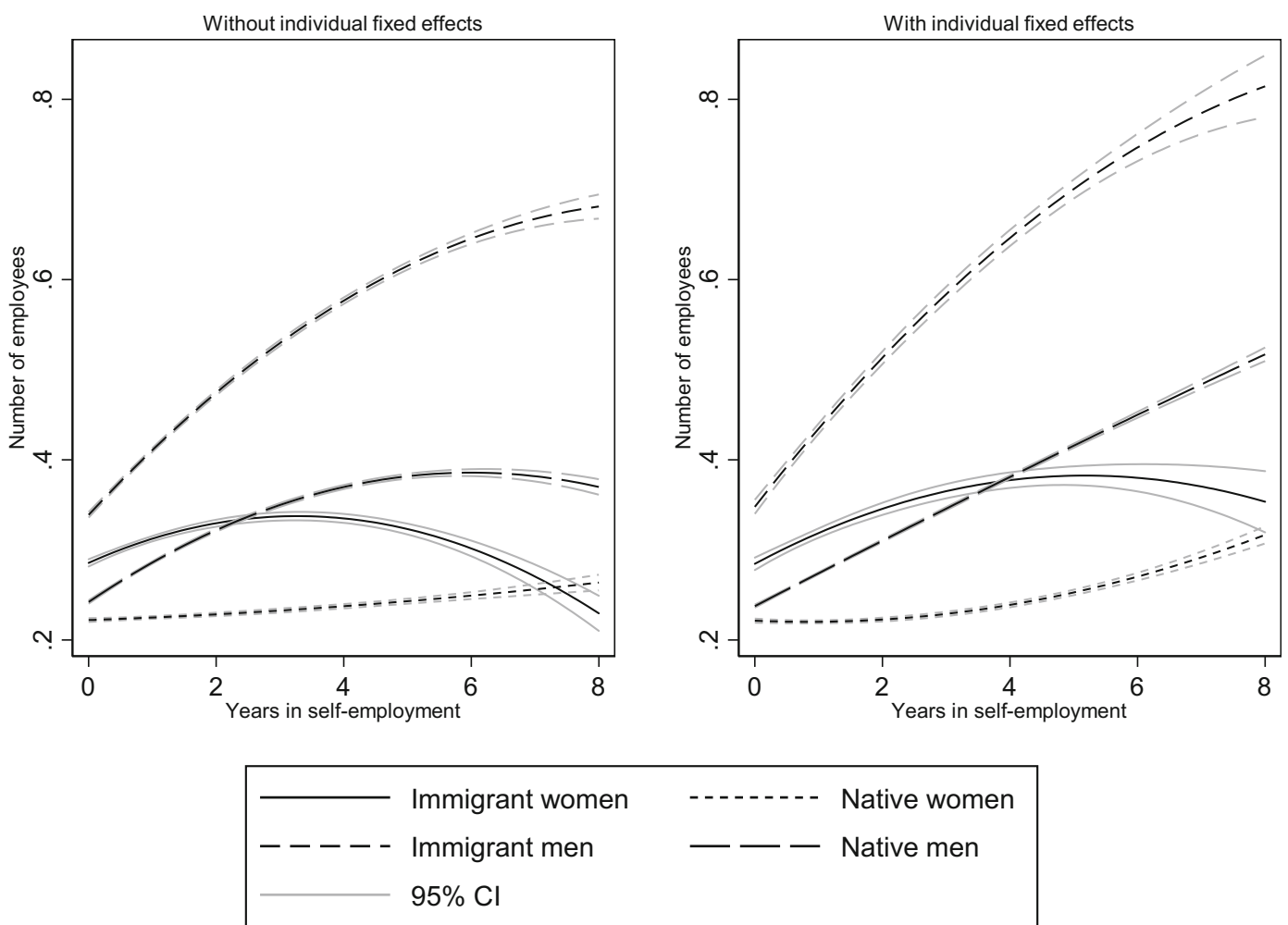

Fig. 7 Predicted number of employees at firm by years in self-employment 
Open Access This article is distributed under the terms of the Creative Commons Attribution 4.0 International License (http:// creativecommons.org/licenses/by/4.0/), which permits unrestricted use, distribution, and reproduction in any medium, provided you give appropriate credit to the original author(s) and the source, provide a link to the Creative Commons license, and indicate if changes were made.

\section{References}

Aldén, L., \& Hammarstedt, M. (2016). Discrimination in the credit market? Access to financial capital among self-employed immigrants. Kyklos, 69(1), 3-31.

Andersson, L., \& Hammarstedt, M. (2011). Invandrares egenföretagande-trender, branscher, storlek och resultat. Ekonomisk Debatt, 39(2), 31-39.

Andersson Joona, P. (2010). Exits from self-employment: Is there a native-immigrant difference in Sweden? International Migration Review, 44(3), 539-559.

Andersson Joona, P. (2011). The native-immigrant income gap among the self-employed in Sweden. International Migration, 49(4), 118-143.

Asiedu, E., Freeman, J. A., \& Nti-Addae, A. (2012). Access to credit by small businesses: How relevant are race, ethnicity, and gender? American Economic Review, 102(3), 532-537.

Åstebro, T., \& Tåg, J. (2017). Gross, net, and new job creation by entrepreneurs. Journal of Business Venturing Insights, 8, 64 70.

Barth, E., Bratsberg, B., \& Raaum, O. (2004). Identifying earnings assimilation of immigrants under changing macroeconomic conditions. Scandinavian Journal of Economics, 106(1), 122.

Bates, T. (1999). Existing self-employment: An analysis of Asian immigrant-owned small businesses. Small Business Economics, 13(3), 171-183.

Blackburn, R., \& Ram, M. (2006). Fix or fixation? The contributions and limitations of entrepreneurship and small firms to combating social exclusion. Entrepreneurship and Regional Development, 18(1), 73-89.

Blanchard, L., Zhao, B., \& Yinger, J. (2008). Do lenders discriminate against minority and woman entrepreneurs? Journal of Urban Economics, 63(2), 467-497.

Blanchflower, D. G., Levine, P. B., \& Zimmerman, D. J. (2003). Discrimination in the small-business credit market. Review of Economics and Statistics, 85(4), 930-943.

Borjas, G. J. (1985). Assimilation, changes in cohort quality, and the earnings of immigrants. Journal of Labor Economics, 3(4), 463-489.

Borjas, G. J. (1986). The self-employment experience of immigrants. Journal of Human Resources, 21(4), 485-506.

Borjas, G. J., \& Bronars, S. G. (1989). Consumer discrimination and self-employment. Journal of Political Economy, 97(3), 581-605.

Burke, A. E., Fitzroy, F. R., \& Nolan, M. A. (2002). Selfemployment wealth and job creation: The roles of gender, non-pecuniary motivation and entrepreneurial ability. Small Business Economics, 19(3), 255-270.
Carter, S., \& Shaw, E. (2006). Women's business ownership: Recent research and policy development. London: DTI Small Business Service Research Report.

Chiswick, B. R. (1978). The effect of Americanization on the earnings of foreign-born men. Journal of Political Economy, 86(5), 897-921.

Clark, K., \& Drinkwater, S. (2000). Pushed out or pulled in? Selfemployment among ethnic minorities in England and Wales. Labour Economics, 7, 603-628.

Clark, K., \& Drinkwater, S. (2010). Patterns of ethnic selfemployment in time and space: Evidence from British census microdata. Small Business Economics, 34(3), 323-338.

Constant, A., \& Zimmermann, K. F. (2006). The making of entrepreneurs in Germany: Are native men and immigrants alike? Small Business Economics, 26(3), 279-300.

Constant, A., Shachmurove, Y., \& Zimmermann, K. F. (2007). What makes an entrepreneur and does it pay? Native men, Turks, and other migrants in Germany. International Migration, 45(4), 71-100.

Cowling, M., Taylor, M., \& Mitchell, P. (2004). Job creators. Manchester School, 72(5), 601-617.

Fairlie, R. W., \& Lofstrom, M. (2015). Immigrant entrepreneurship. In B. Chiswick \& P. Miller (Eds.), Handbook of the economics of international immigration (Vol. 1B). Amsterdam: Elsevier.

Fairlie, R. W., \& Meyer, B. D. (1996). Ethnic and racial selfemployment differences and possible explanations. Journal of Human Resources, 31(4), 757-793.

Fairlie, R. W., \& Miranda, J. (2017). Taking the leap: The determinants of entrepreneurs hiring their first employee. Journal of Economics \& Management Strategy, 26(1), 3-34.

Fairlie, R. W., \& Robb, A. M. (2007). Why are black-owned businesses less successful than white-owned businesses? The role of families, inheritances, and business human capital. Journal of Labor Economics, 25(2), 289-323.

Gurley-Calvez, T., Biehl, A., \& Harper, K. (2009). Time-use patterns and women entrepreneurs. American Economic Review, 99(2), 139-144.

Hammarstedt, M. (2001). Immigrant self-employment in Swedenits variation and some possible determinants. Entrepreneurship and Regional Development, 13(2), 147161.

Hammarstedt, M. (2006). The predicted earnings differential and immigrant self-employment in Sweden. Applied Economics, 38(6), 619-630.

Henley, A. (2005). Job creation by the self-employed: The roles of entrepreneurial and financial capital. Small Business Economics, 25(2), 175-196.

Kerr, S. P., \& Kerr, W. R. (2017). Immigrant entrepreneurship. In J. Haltiwanger, E. Hurst, J. Miranda, \& A. Schoar (Eds.), Measuring entrepreneurial businesses: Current knowledge and challenges, Vol. 75 (chapter 5). Chicago: University of Chicago Press.

Kloosterman, R. C. (2010). Matching opportunities with resources: A framework for analysing (migrant) entrepreneurship from a mixed embeddedness perspective. Entrepreneurship and Regional Development, 22(1), 25-45.

Koellinger, P., Minniti, M., \& Schade, C. (2013). Gender differences in entrepreneurial propensity. Oxford Bulletin of Economics and Statistics, 75(2), 213-234. 
Lofstrom, M. (2002). Labor market assimilation and the selfemployment decision of immigrant entrepreneurs. Journal of Population Economics, 15(1), 83-114.

Lofstrom, M. (2011). Low-skilled immigrant entrepreneurship. Review of Economics of the Household, 9(1), 25-44.

Lundh, C., \& Ohlsson, R. (1999). Från arbetskraftsimport till flyktinginvandring (2nd ed.). Stockholm: SNS.

Parker, S. C. (2009). The economics of entrepreneurship. New York: Cambridge University Press.

Robb, A. M., \& Fairlie, R. W. (2009). Determinants of business success: An examination of Asian-owned businesses in the USA. Journal of Population Economics, 22(4), 827-858.

Schuetze, H. J., \& Antecol, H. (2006). Immigration, entrepreneurship and the venture start-up process. In S. Parker (Ed.), The life cycle of entrepreneurial ventures. International handbook series on entrepreneurship (pp. 107-135). New York: Springer.

Shane, S. A. (2003). A general theory of entrepreneurship: The individual-opportunity nexus. Cheltenham: Edward Elgar.

Simoes, N., Crespo, N., \& Moreira, S. B. (2016). Individual determinants of self-employment entry: What do we really know? Journal of Economic Surveys, 30(4), 783-806.

SOU 2015/16:100 "2016 års ekonomiska vårproposition".

Statistics Sweden. (n.d.). Various years. Statistical yearbook. Accessed at: http://www.scb.se/en_/Finding-
statistics/Statistics-by-subject-area/Other/Other/StatisticalYearbook-of-Sweden/ Accessed 17 October 2016.

Storey, D. J. (1994). Understanding the small business sector. London: Routledge.

Van der Sluis, J., Van Praag, M., \& Vijverberg, W. (2008). Education and entrepreneurship selection and performance: A review of the empirical literature. Journal of Economic Surveys, 22(5), 795-841.

Van Praag, C. M., \& Cramer, J. S. (2001). The roots of entrepreneurship and labour demand: Individual ability and low risk aversion. Economica, 68(269), 45-62.

Waldinger, R. D., Aldrich, H., \& Ward, R. (1990). Ethnic entrepreneurs: Immigrant business in industrial societies. Newbury Park, CA: Sage.

Wellington, A. J. (2006). Self-employment: The new solution for balancing family and career? Labour Economics, 13(3), 357386.

Zorn, C. (2005). A solution to separation in binary response models. Political Analysis, 13(2), 157-170.

Publisher's note Springer Nature remains neutral with regard to jurisdictional claims in published maps and institutional affiliations. 